THE ELIMINATION OF ETHYL IODIDE AFTER INHALATION AND ITS RELATION TO THERAPEUTIC ADMINISTRATION ${ }^{1}$

\author{
BY HERRMAN L. BLUMGART, DOROTHY ROURKE GILLIGAN \\ AND JACOB H. SWARTZ
}

(From the Research Laboratories of the Beth Israel Hospital and the Departments of Medicine and Dermatology of the Harvard Medical School, Boston)

(Received for publication June 30, 1930)

Previous communications have demonstrated the advantages of inhalation of ethyl iodide in treating certain diseases $(1,2)$. Two hundred patients with epidermophytosis, tinea capitis, tinea favosa, monilia infections, cryptococcosis epidermica, blastomycosis and other mycotic infections have been treated by means of inhalations of ethyl iodide. Many of these patients, treated for a period of years with unsatisfactory results by the methods hitherto available, have shown striking improvement and even complete recovery. No reports of the therapeutic use of ethyl iodide by other investigators were available in the literature. The purpose of the present investigation was to study the elimination of ethyl iodide after inhalation in order to establish the optimum dosage and frequency of treatment, and to gain knowledge concerning the mechanism of its action.

AMOUNT OF ETHYL IODIDE RETAINED IN BODY AT THE END OF INHALATION PERIOD

The first object of the study was to measure the amount of ethyl iodide remaining in the body at the termination of the inhalation of the ethyl iodide vapor.

The ethyl iodide ${ }^{2}$ was weighed, or was measured by means of a

1 This investigation was aided by a grant from the DeLamar Mobile Research Fund of Harvard University.

${ }^{2}$ All ethyl iodide used in this investigation was obtained by repurification of Merck's ethyl iodide according to directions given by Fisher (11). Ethyl iodide which has been properly prepared is colorless, has a specific gravity of 1.94 at $15^{\circ} \mathrm{C}$., a boiling point of $72.2^{\circ} \mathrm{C}$. and is phosphorus-free. It should be stored in a brown bottle. The addition of a globule of mercury will keep the product colorless. 


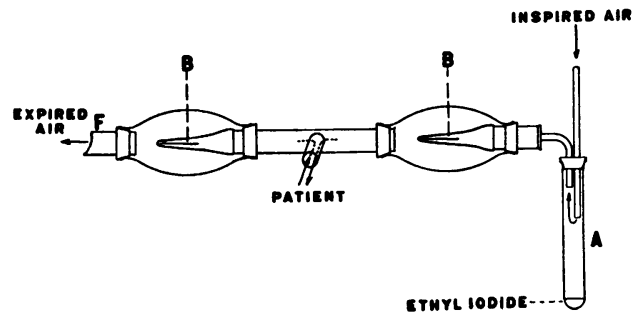

Fig. 1. Diagram of Apparatus Used in the Investigation

The inspired air is drawn through test tube $A$ containing the ethyl iodide. The concentration of ethyl iodide in the inspired air can be varied by altering the degree to which the straight glass tube projects into the test tube. Rebreathing is prevented by the use of flutter valves $B, B$. The expired air passes through outlet tube $F$. For clinical purposes a simpler, more practical apparatus has been devised.

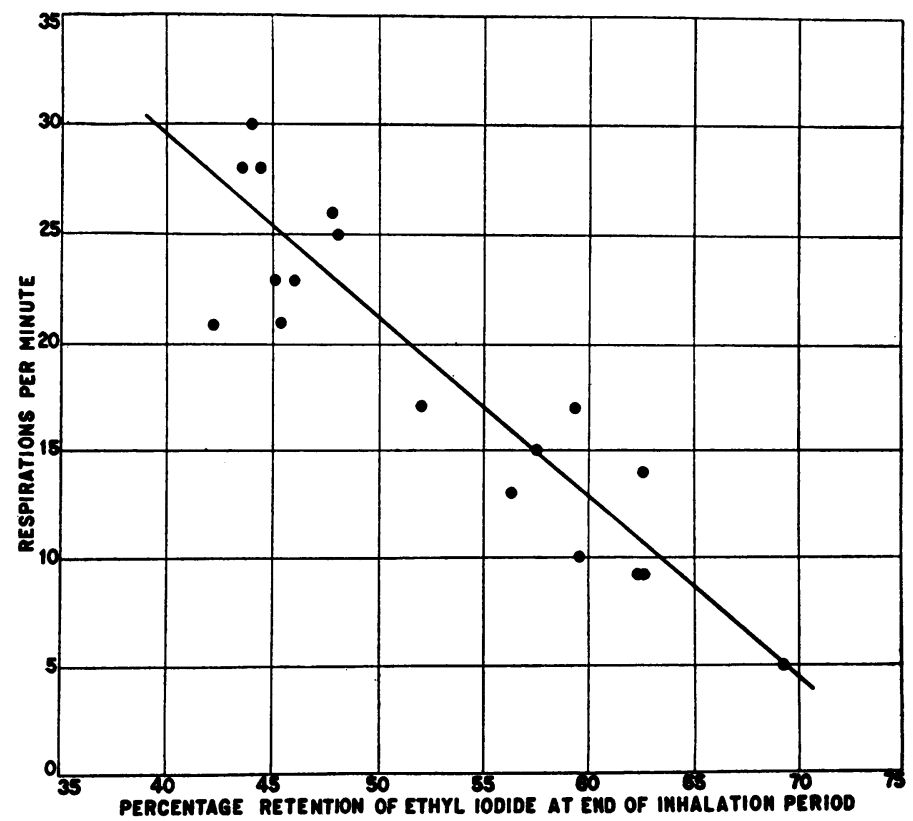

Fig. 2. The Relation Between the Respiratory Rate and the Percentage of Ethyl Iodme Retained within the Body at the Immediate ConClusion of the Inhalation Period 
United States Bureau of Standards pipette. The desired amount was transferred to a test tube $(A$, fig. 1$)$. The apparatus was constructed to permit partial saturation of the inspiratory current of air with ethyl iodide vapor. The two way flutter valve system $B$ (fig. 1)

TABLE 1

A mount of ethyl iodide retained in body at end of inhalation period

\begin{tabular}{|c|c|c|c|c|c|c|c|c|c|}
\hline $\begin{array}{c}\text { Measure- } \\
\text { ment } \\
\text { number }\end{array}$ & Subject & Date & $\begin{array}{l}\text { Dura- } \\
\text { tion of } \\
\text { inhala- } \\
\text { tion }\end{array}$ & $\begin{array}{l}\text { Respir- } \\
\text { atory } \\
\text { minute } \\
\text { volume }\end{array}$ & $\begin{array}{l}\text { Respi- } \\
\text { rations } \\
\text { per } \\
\text { minute }\end{array}$ & $\begin{array}{c}\text { Amount } \\
\text { of } \\
\text { ethyl } \\
\text { iodide } \\
\text { inhaled }\end{array}$ & $\begin{array}{c}\text { Amount } \\
\text { exhaled } \\
\text { during } \\
\text { period of } \\
\text { inhala- } \\
\text { tion }\end{array}$ & $\begin{array}{c}\text { Amount } \\
\text { retained } \\
\text { at end } \\
\text { of } \\
\text { treatment }\end{array}$ & $\begin{array}{c}\text { Per cent } \\
\text { of total } \\
\text { retained } \\
\text { at end } \\
\text { of treat- } \\
\text { ment }\end{array}$ \\
\hline & & 1930 & minutes & liters & & grams & grams & grams & per cont \\
\hline 1 & S. B. & January 23 & 10 & 10.2 & 21 & 1.94 & 1.12 & 0.82 & 42.2 \\
\hline 2 & S. B. & January 27 & 26 & 9.0 & 23 & 1.93 & 1.06 & 0.87 & 45.1 \\
\hline 3 & S. B. & January 30 & 39 & 8.5 & 23 & 3.64 & 1.96 & 1.68 & 46.1 \\
\hline 4 & S. B. & February 4 & 38 & 8.7 & 21 & 5.76 & 3.14 & 2.62 & 45.5 \\
\hline 5 & M. K. & February 4 & 35 & 8.8 & 30. & $3.82^{\circ}$ & 2.14 & 1.68 & 44.0 \\
\hline 6 & H. C. & February 6 & 20 & 10.6 & 28 & 1.94 & 1.08 & 0.86 & 44.3 \\
\hline 7 & H. C. & February 10 & 30 & 11.3 & 28 & 3.68 & 2.08 & 1.60 & 43.5 \\
\hline 8 & H. C. & February 13 & 33 & 9.8 & 25 & 5.00 & 2.60 & 2.40 & 48.0 \\
\hline 9 & E. $R$. & February 3 & 32 & 9.0 & 26 & 4.96 & 2.58 & 2.38 & 48.0 \\
\hline 10 & R. A. & January 31 & 25 & 11.9 & 17 & 4.10 & 2.00 & 2.10 & 51.3 \\
\hline 11 & J. E. & January 31 & 40 & 7.4 & 13 & 5.44 & 2.38 & 3.06 & 56.3 \\
\hline 12 & M. G. & January 24 & 25 & 7.2 & 10 & 3.88 & 1.57 & 2.31 & 59.6 \\
\hline 13 & M. G. & January 27 & 43 & 7.8 & 15 & 3.30 & 1.40 & 1.90 & 57.6 \\
\hline 14 & H. D. & January 29 & 26 & 10.8 & 17 & 5.82 & 2.38 & 3.44 & 59.2 \\
\hline 15 & M. V. & Feb & 17 & 8.0 & 14 & 1.94 & 0. & 1.2 & 62.9 \\
\hline 16 & M. V. & Febru & 22 & 6.2 & 9 & 1.94 & 0.73 & 1.21 & 62.4 \\
\hline 17 & M. V. & February 24 & 47 & 6.3 & 9 & 5.82 & 2.17 & 3.65 & 62.8 \\
\hline 18 & C. $\mathrm{V}$. & March 14 & 60 & 5.5 & 5 & 5.82 & 1.81 & 4.01 & 69.0 \\
\hline
\end{tabular}

communicated directly with a Tissot spirometer of four hundred liter capacity in which the total amount of expired air was collected and measured. The inside of the spirometer was coated with red lead. Gas samples of $250 \mathrm{cc}$. were taken from the spirometer and the 
ethyl iodide content measured according to the method of Starr and Gamble (3). We have been able by this method to recover known amounts of ethyl iodide with a high degree of accuracy. The total amount of exhaled ethyl iodide could then be calculated. The difference between the amount of ethyl iodide volatilized in the inspired air and the amount exhaled represented the amount remaining within the body at the immediate conclusion of a treatment.

The results of eighteen measurements in ten different subjects are shown in table 1. The amount of ethyl iodide inhaled varied from 1.93 to 5.82 grams. In different individuals, the percentage of ethyl iodide retained in the body varied from 42.2 to 69.0 per cent of that inhaled; but, in a given individual, the percentage retained in successive experiments was remarkably constant, regardless of the amount inhaled. In subject S. B., for example, 1.93 to 5.76 grams of ethyl iodide were inhaled but the percentage retained varied only from 42.2 to 46.1 per cent. The percentage of ethyl iodide retained was not affected by the length of time taken for inhalation (table 1). The percentage retained depended to a large extent, however, on the respiratory rate; the lower the respiratory rate, the greater the percentage retention (fig. 2). With lower respiratory rates more time is probably available for effective absorption of ethyl iodide by the blood of the alveolar capillaries. In subjects with normal respiratory rates, the average retention of ethyl iodide in the body at the conclusion of treatment was 55 per cent of the total amount inhaled.

THE AMOUNT OF ETHYL IODIDE EXHALED AFTER END OF INHALATION PERIOD

Besides the ethyl iodide exhaled during treatment, additional amounts were exhaled after treatment. To study this latter factor the following method was used. Ethyl iodide was administered according to the procedure described above except that the outlet tube $F$ (fig. 1) was led to the air outside the laboratory to prevent reinhalation of the ethyl iodide exhaled during the treatment. As soon as all the ethyl iodide in test tube $(A)$ (fig. 1) had been vaporized, the test tube was removed and the expired air collected in a Tissot spirometer at appropriate intervals for five or ten minute periods. The total volume of expired air during each period was measured, 
and samples of 250 to $1000 \mathrm{cc}$. were taken and analyzed. From these data, the total amount of ethyl iodide exhaled during any given period of time as well as the average number of milligrams of ethyl iodide exhaled per minute could be calculated. By means of these results curves of excretion were plotted (fig. 3). The final portions of the curves (dotted line) of excretion were estimated since the concentration of ethyl iodide became too small to be measured.

Indirect evidence in regard to the approximate accuracy of the terminal portions of the curves was obtained by analysis of samples of alveolar air. The concentration of ethyl iodide in the alveolar

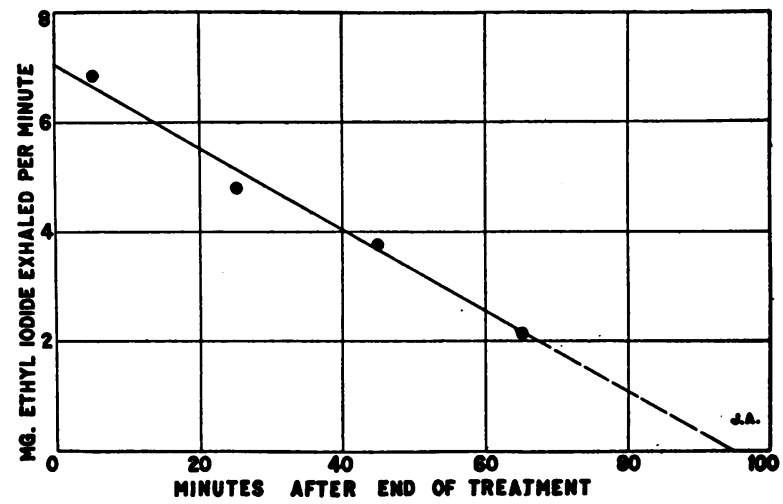

Fig. 3. The Rate at Which Ethyt Iodme is Grven Off in the Expired Arr Following TREATMENT

air would be higher than that of the total expired air inasmuch as the expired air collected in the usual manner represents alveolar air diluted by air of the dead space. The absence of ethyl iodide in the alveolar air collected after the projected portion of the curve had reached zero would be confirmatory evidence of the accuracy of this part of the graph. Ninety to 120 minutes after the conclusion of treatment, samples were obtained by collecting the air of successive forced expirations until a total of one liter was obtained. Four analyses in two subjects showed no detectable amounts of ethyl iodide.

The total amount of ethyl iodide exhaled could, therefore, be calculated by integrating the area under the curve. Thirteen series of measurements were made in eight subjects (table 2). The length of 
time ethyl iodide continued to be exhaled following treatment and the total amount of ethyl iodide exhaled were apparently unrelated to such factors as dosage, duration of treatment or respiratory rate of the patient. The average amount of ethyl iodide exhaled after the end of the inhalation period was 0.35 gram or 9 per cent of the mean total dose.

TABLE 2

The amount of ethyl iodide exhaled after end of inhalation period and related data

\begin{tabular}{c|c|c|c|c|c|c}
\hline $\begin{array}{c}\text { Measure- } \\
\text { ment } \\
\text { number }\end{array}$ & Name & $\begin{array}{c}\text { Amount } \\
\text { ethyl iodide } \\
\text { inhaled }\end{array}$ & $\begin{array}{c}\text { Duration } \\
\text { of inhalation } \\
\text { period }\end{array}$ & $\begin{array}{c}\text { Respirations } \\
\text { per minute }\end{array}$ & $\begin{array}{c}\text { Time after } \\
\text { inhalation when } \\
\text { ethyl iodide } \\
\text { ceases } \\
\text { to be exhaled }\end{array}$ & $\begin{array}{c}\text { Total amount } \\
\text { of ethyl iodide } \\
\text { exhaled } \\
\text { after end of } \\
\text { inhalation } \\
\text { period }\end{array}$ \\
\hline & grams & minutes & & minutes & grams \\
1 & M. V. & 1.94 & 17 & 16 & 107 & 0.44 \\
2 & C. V. & 1.94 & 23 & 5 & 98 & 0.22 \\
3 & H. N. & 1.94 & 24 & 16 & 82 & 0.20 \\
4 & W. M. & 1.94 & 20 & 25 & 60 & 0.36 \\
5 & M. V. & 3.88 & 35 & 11 & 45 & 0.42 \\
6 & M. V. & 3.88 & 30 & 9 & 62 & 0.36 \\
7 & R. P. & 3.88 & 38 & 22 & 97 & 0.18 \\
8 & S. B. & 5.67 & 39 & 29 & 117 & 0.54 \\
9 & J. E. & 5.82 & 36 & 13 & 68 & 0.45 \\
10 & M. V. & 5.82 & 47 & 16 & 100 & 0.55 \\
11 & J. A. & 5.82 & 45 & 22 & 94 & 0.33 \\
12 & C. V. & 5.82 & 60 & 5 & 103 & 0.25 \\
13 & C. V. & 5.82 & 50 & 6 & 49 & 0.29 \\
\hline
\end{tabular}

\section{EXCRETION OF IODIDE IN THE URINE}

The next object of the investigation was to learn in what manner and at what rate the remainder of the ethyl iodide was excreted. Ten specimens of urine collected immediately following treatment were analyzed for ethyl iodide by the method of Starr and Gamble (4). No free ethyl iodide could be detected.

Other investigators $(5,6,7$, etc.) have shown that the major portion of inorganic iodine salts administered orally, rectally, or intravenously is excreted as iodide in the urine. In the present investigation all urine was collected over a period of days following treatment, the time of voiding, the volume and the iodide content 


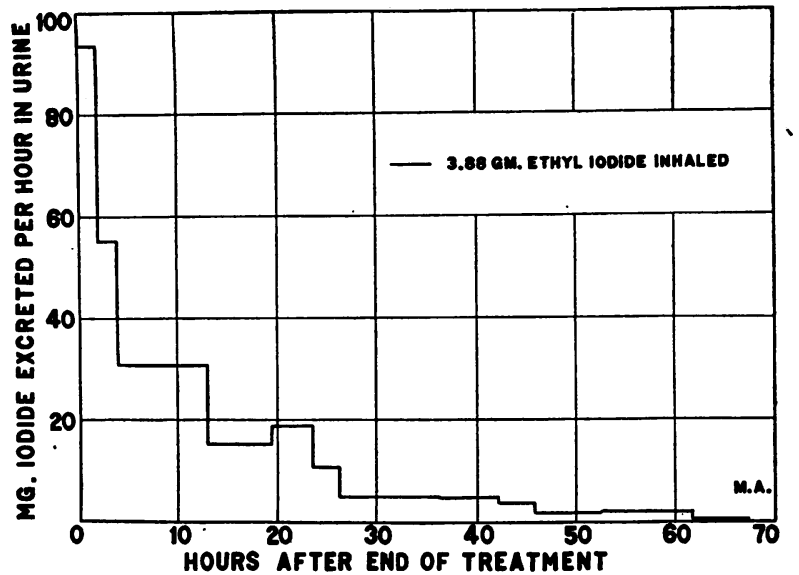

Fig. 4. Excretion per Hour of Iodme in the Urine after Subject (M. A.) Had InHaled 3.88 Grams Ethyl Iodme

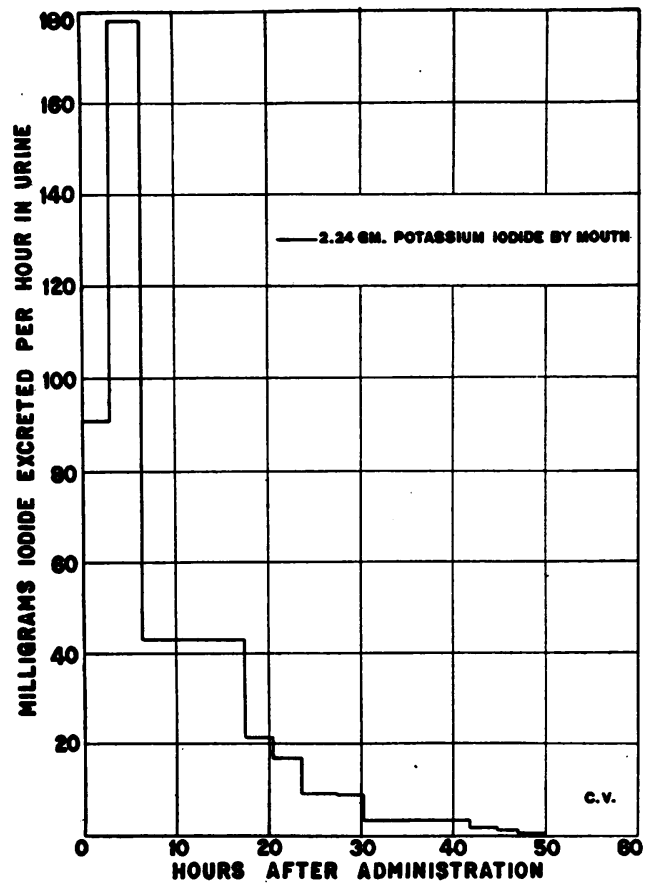

Fig. 5. Excretion per Hour of Iodide in the Urine after Subject (C. V.) Received 2.24 Grams of Potassium Iodme by Mouth 


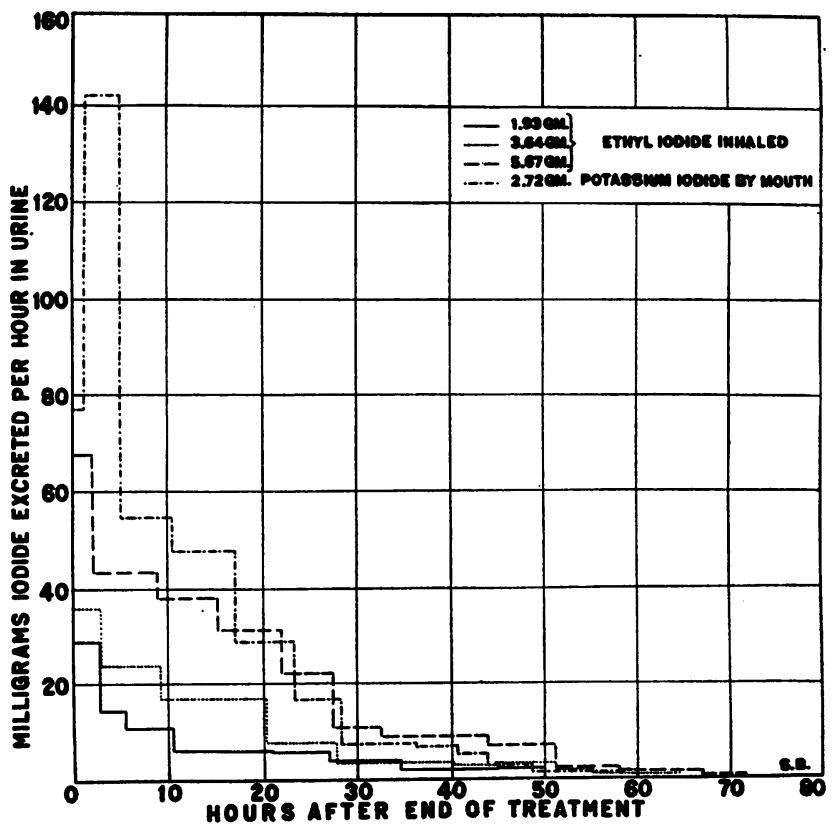

Fig. 6. Rate of Excretion of Iodide in the Urine in Subject (S. B.) after InHalation of Various Amounts of Ethyl Iodide aNd after Potassium IODIDE BY MOUTH

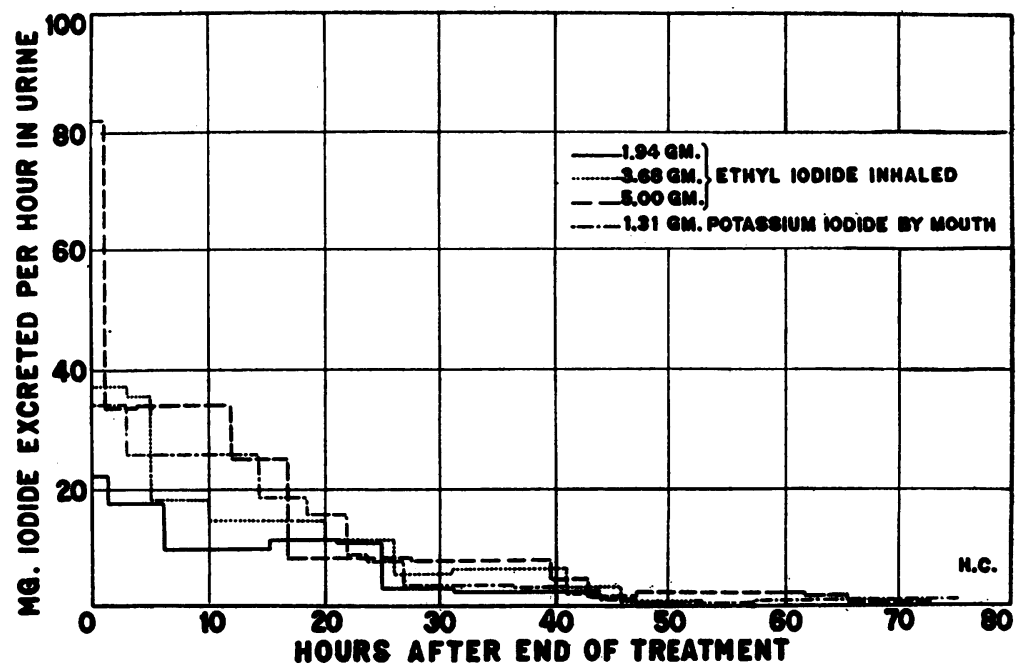

Fig. 7. Excretion of IODIDE in Urine after Various Amounts of Ethyl Iodme Had Been INHaled aNd after Potassium Iodide by Mouth Had Been Given to SubJect (H. C.) 
of each specimen being recorded. From these data the hourly excretion of iodide was calculated. The iodide excreted in the urine after ethyl iodide inhalation was compared with that following the administration of similar doses of potassium iodide by mouth. The method used for measuring the iodide in the urine was substan-

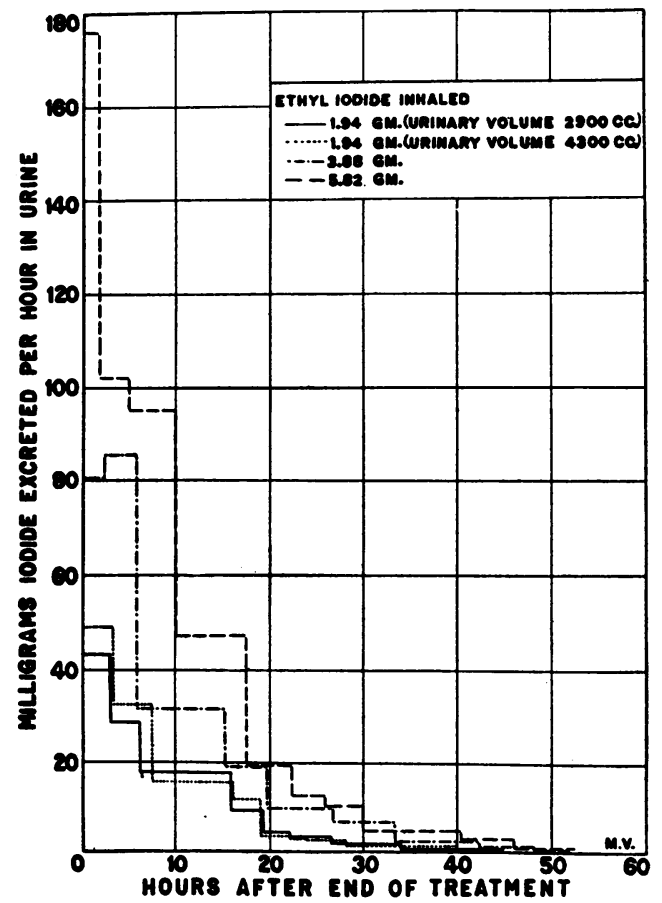

Fig. 8. EXcretion of Iodide IN URINe afTer Various Doses of Ethyl Iodide Had Been Given to Subject (M. V.)

The effect of urinary volume on excretion was studied by doubling the fluid intake after the second dose of 1.94 grams of ethyl iodide had been taken. The two curves of excretion closely correspond.

tially that of Bolliger (8). Charcoal was substituted for Lloyd's reagent. The oxidizing reagent consisted of a ten per cent solution of sodium nitrite in concentrated sulphuric acid. Standards were made containing 0.5 to $6.0 \mathrm{mgm}$. of iodine in $25 \mathrm{cc}$. of $\mathrm{CCl}_{4}$. Small test tubes of uniform diameter were employed in the colorimetric comparison of the standard and unknown solutions. 
Figures 4, 5, 6, 7 and 8 show the hourly excretion of iodide in the urines of five subjects after the administration of various amounts of ethyl iodide by inhalation and of potassium iodide by mouth. The curves of iodide excretion after ethyl iodide and potassium iodide are of the same general type, the rate and duration of excretion being strikingly similar.

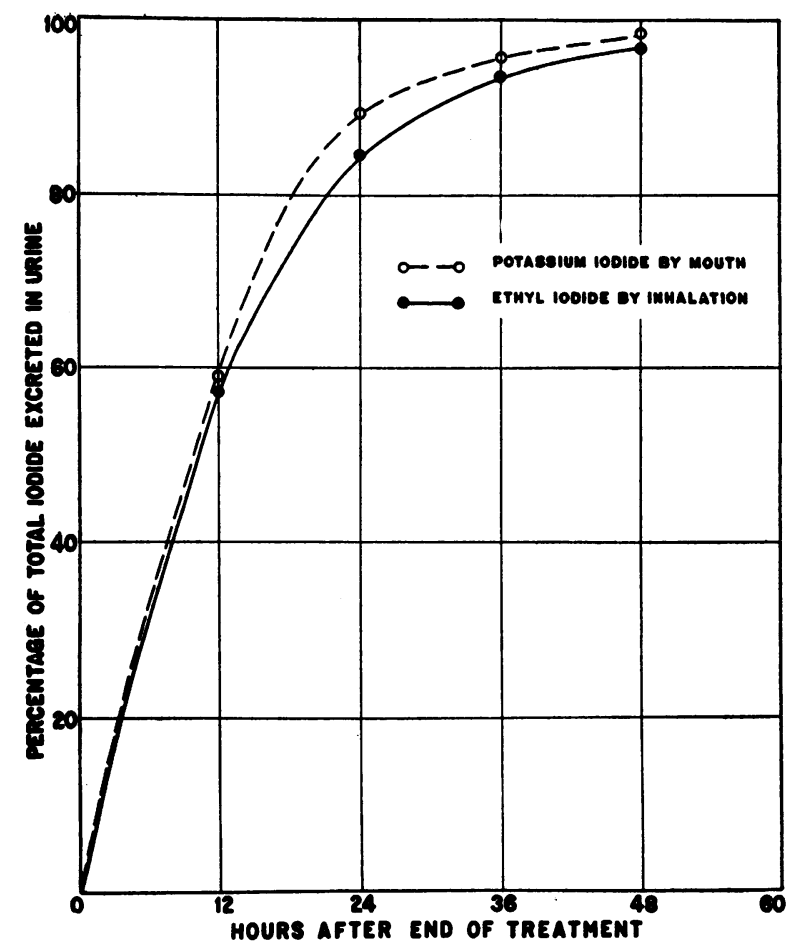

Fig. 9. The Average Rate of Iodme Excretion Expressed as Percentage OF THE TOTAL EXCRETED IN THE URINE

Curves showing the percentage excretion during successive 12-hour periods following treatment varied but slightly in all subjects regardless of the dosage. The average rate of iodide excretion expressed as the percentage of the total excreted in the urine is shown in figure 9.

In a given patient, urinary excretion of iodide ceased after approximately the same time interval regardless of the amount of ethyl iodide inhaled (table 3). The duration of excretion was not altered 
appreciably by doubling the fluid intake (solid and dotted lines, figure 8). That the volume of urine did not affect the rate of excretion

TABLE 3

Measurements of excretion of iodide in urine

\begin{tabular}{|c|c|c|c|c|c|c|c|c|c|c|}
\hline & & & A & B & $\mathrm{C}$ & D & E & $\mathrm{F}$ & G & H \\
\hline 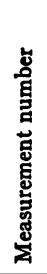 & Subject & Date & 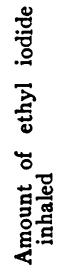 & 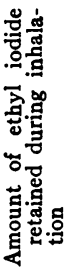 & 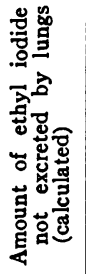 & 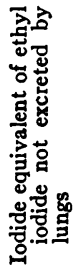 & 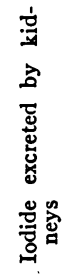 & 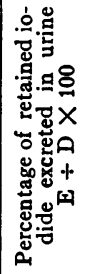 & 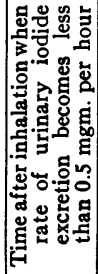 & 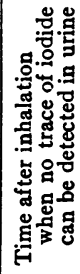 \\
\hline & & 1930 & grams & grams & grams & grams & grams & per cent & hours & hours \\
\hline 1 & S. B. & January 27 & 1.93 & 0.87 & 0.52 & 0.42 & 0.32 & 76 & $>50$ & \\
\hline 2 & S. B. & January 30 & 3.64 & 1.68 & 1.33 & 1.08 & 0.58 & 54 & 65 & 113 \\
\hline 3 & S. B. & February 10 & 5.82 & 2.64 & 2.29 & 1.86 & 1.35 & 73 & 67 & 114 \\
\hline 4 & S. B. & February 19 & 5.67 & 2.58 & 2.23 & 1.81 & 1.23 & 68 & 72 & 124 \\
\hline 5 & H. C. & February 6 & 1.94 & 0.86 & 0.51 & 0.41 & 0.35 & 85 & $>44$ & 71 \\
\hline 6 & H. C. & February 10 & 3.68 & 1.60 & 1.25 & 1.02 & 0.59 & 58 & 53 & $>77$ \\
\hline 7 & H. C. & February 13 & 5.00 & 2.44 & 2.09 & 1.70 & 0.78 & & 73 & 109 \\
\hline 8 & M. V. & & 1.94 & 1.22 & 0.87 & 0.71 & 0.45 & 64 & 45 & 94 \\
\hline 9 & M. V. & February 18 & 1.94 & 1.21 & 0.86 & 0.70 & 0.51 & 73 & 40 & 71 \\
\hline 10 & M. V. & April 3 & 3.88 & 2.43 & 2.08 & 1.69 & 1.02 & 61 & 51 & 80 \\
\hline 11 & M. V. & February 24 & 5.82 & 3.65 & 3.30 & 2.68 & 1.71 & 64 & 52 & 95 \\
\hline
\end{tabular}

TABLE 4

Percentage excretion of iodide in urine after administration of potassium iodide

\begin{tabular}{c|c|c|c|c|c}
\hline $\begin{array}{c}\text { Measurement } \\
\text { number }\end{array}$ & Subject & $\begin{array}{c}\text { Amount } \\
\text { potassium iodide } \\
\text { administered } \\
\text { by mouth }\end{array}$ & $\begin{array}{c}\text { Iodide } \\
\text { equivalent }\end{array}$ & $\begin{array}{c}\text { Amount } \\
\text { iodide excreted } \\
\text { in urine }\end{array}$ & $\begin{array}{c}\text { Urinary iodide } \\
\text { excretion } \\
\text { calculated } \\
\text { as percentage of } \\
\text { intake }\end{array}$ \\
\hline 1 & H. C. & 1.31 & grams & grams & per cent \\
2 & C. V. & 2.24 & 1.00 & 0.64 & 64 \\
3 & S. B. & 2.72 & 2.08 & 1.42 & 83 \\
\end{tabular}

was also shown by the fact that S. B. continued to excrete iodide in the urine for a somewhat greater length of time than H. C. or M. V. 
(table 3) although the urinary volume of the latter subjects was approximately one-half as great.

The total amounts of iodide excreted in the urine of three patients after doses of potassium iodide by mouth are given in table 4 . Of the total iodide ingested an average of 75 per cent was excreted by the kidneys. These results are in accord with observations of others $(5,6,7$, etc.). The remainder of the iodide, according to these investigators, is excreted by the intestines, the skin, and in the sputum. Of the total amount of ethyl iodide not eliminated by the lungs, an average of 68 per cent (table 3 ) is excreted by the kidneys as iodide. It is reasonable to conclude that the remainder of the iodide is excreted in the same manner as mentioned above. Excluding the ethyl

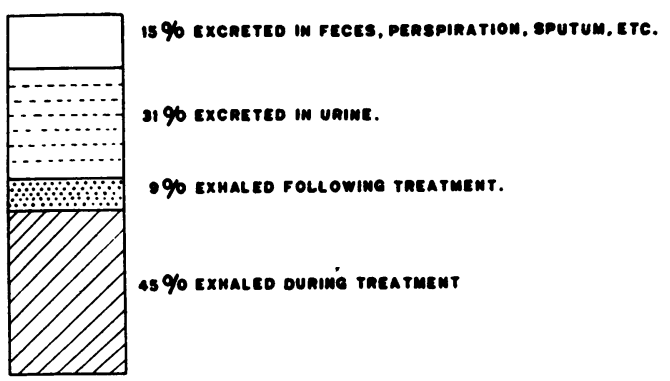

Fig. 10. Diagrammatic Representation of the Fate of Ethyl Iodide ORIGINALLY INHALED

iodide given off by the lungs, our results indicate the similarity in the excretion of iodides, whether administered originally as the organic compound, ethyl iodide; or as an inorganic salt, potassium iodide.

In brief, one may conclude that after 1.0 to $3.0 \mathrm{cc}$. of ethyl iodide are inhaled, an average of 45 per cent is immediately exhaled during treatment, 9 per cent is exhaled during the first 2 hours after treatment and 31 per cent is excreted by the kidneys. This accounts for 85 per cent of the total dose given, the other 15 per cent being excreted in all probability by the intestines, skin, and in the sputum (fig. 10).

\section{DISCUSSION}

Frequency and amount of dosage. The action of a drug depends in large part on its concentration within the body. It is consequently 
desirable to maintain a high level of concentration of the drug in the body by administering sufficient amounts at appropriate intervals to offset excretion of the substance. Elimination of ethyl iodide takes place through the lungs, the kidneys, the gastro-intestinal tract, and in the sputum. The results of the present investigation demonstrate that a total of 54 per cent of the inhaled ethyl iodide is exhaled during treatment and within the first few hours immediately following treatment. Measurements of the elimination of iodide in the urine after inhalation of ethyl iodide offer important evidence regarding the amount remaining within the body since 68 per cent of the ethyl iodide not exhaled during and immediately following treatment, is excreted as iodide in the urine (table 3). The rate of excretion is greatest immediately following treatment and decreases rapidly. Approximately 85 per cent of the total urinary iodide is excreted within the first 24 hours and approximately 97 per cent is excreted by the end of 48 hours. This indicates that daily repetition of the dosage is desirable to maintain a high level of iodide within the body; that is to say, a given dose repeated daily will maintain a higher level of concentration than twice that dose given every other day. It should be noted, however, that since 15 per cent or more remains within the body, daily repetition will lead to accumulation and, ultimately to toxic effects. To prevent such an occurrence, the daily dosage could be reduced on each successive day, but practically, the same purpose may be achieved by omitting treatment every third or fourth day. Forty-eight hours will then elapse between two treatments, an interval of time sufficiently great to permit almost complete elimination of the accumulated iodide. The amount of the daily dosage of ethyl iodide must depend largely on the therapeutic results and the absence of toxic effects as observed clinically. Clinical experience up to the present indicates that daily doses of 4 grams are efficacious but further experience is necessary to establish this more precisely. Future communications will give further information regarding this point.

Influence of fluid and food intake on excretion of iodide. The water intake during treatment need not be regulated since the excretion of iodide seems to be independent of the fluid ingested (fig. 8). The influence of diet was not studied since the iodide content of food is so 
small that the effect may be considered unimportant for these purposes. It is probable, that in the presence of toxicity, increased amounts of sodium chloride in the diet will facilitate excretion.

Contraindications to the use of ethyl iodide. Impaired excretory function of the kidney will probably favor retention of iodide and the appearance of toxic effects. We have therefore been particularly careful to avoid treating subjects with evidence of nephritis. The urine of all subjects was examined previous to and following treatment in order to exclude any possible untoward effects on kidney function. No evidence of renal irritation was observed. Ethyl iodide was not administered to any patients with symptoms or signs of thyrotoxicosis.

Mechanism of action of ethyl iodide. The use of ethyl iodide was originally suggested because it is an unstable compound which can be absorbed directly into the arterial circulation and so reach the peripheral tissues in high concentration. Ethyl iodide is only slightly soluble in water so that intravenous administration would be inadvisable. If given intravenously a part of the ethyl iodide would, moreover, be given off immediately by the lungs before it reached the arterial blood. The investigations of Henderson and Haggard (9), and of Starr and Gamble (10) indicate that more than threequarters of inhaled ethyl iodide is immediately hydrolyzed in the arterial and capillary blood before it reaches the veins. Some of the ethyl iodide, however, passes into the tissues during inhalation and accumulates there in increasing amounts, as shown by the fact that, after ethyl iodide inhalation is discontinued, venous concentration of ethyl iodide exceeds arterial concentration. The exact changes that occur in the peripheral blood are still obscure. Minute amounts of free iodine may conceivably be liberated. We have taken blood from patients before and after treatment to learn whether the growth of fungi was less in the latter blood but no significant difference was noted. It is of interest to note that a toxic rash which appeared in a few patients receiving repeated large doses of ethyl iodide was first observed in the diseased areas rather than according to the conventional distribution. The fact that ethyl iodide is a lipoid solvent may also explain in part its striking therapeutic efficacy.

Investigations are planned to study the value of ethyl iodide in other 
diseases and the advantages to be obtained from quantitative inhalation therapy.

\section{SUMMARY AND CONCLUSIONS}

1. The fate of ethyl iodide in the body has been studied after the inhalation of amounts found strikingly effective in treating more than 200 patients with certain skin diseases.

2. The results of this investigation offer a rational basis for determining the optimum dosage and the frequency of treatment.

3. After 1.0 to $3.0 \mathrm{cc}$. of ethyl iodide are introduced into the inspired air, an average of 45 per cent is immediately exhaled during the period of treatment, an average of 9 per cent is exhaled during the first two hours after treatment and 31 per cent is excreted by the kidneys. This accounts for 85 per cent of the total dose given, the other 15 per cent being excreted in all probability by the intestines, skin, and in the sputum.

4. Of the ethyl iodide excreted as iodide in the urine, approximately 85 per cent is excreted within the first 24 hours and approximately 97 per cent is excreted by the end of 48 hours.

5. The results indicate that daily repetition of the treatment is desirable to maintain a high level of iodide within the body.

6. To avoid accumulation of the drug and possible toxic effects, treatment should be omitted every third or fourth day.

7. Within the range of therapeutic dosage, the percentage of ethyl iodide retained in the body is independent of the size of the dose, of the length of time taken for inhalation and of the fluid intake and output.

8. The mechanism of action of ethyl iodide and the contraindications to its use are discussed.

We are indebted to Miss Mary Vastine for technical assistance.

\section{BIBLIOGRAPHY}

1. Swartz, J. H., Blumgart, H. L., and Altschule, M. D., Arch. Dermat. and Syph., 1930, xxi, 182. Ethyl Iodide Inhalations in the Treatment of Mycotic Infections of the Skin and Allied Conditions.

2. Swartz, J. H., Arch. Dermat. and Syph. To be published. Further Clinical Studies in the Treatment of Mycotic Infections with Ethyl Iodide. 
3. Starr, I., Jr., and Gamble, C. J., J. Biol. Chem., 1927, lxxi, 509. A Method for the Determination of Minute Amounts of Ethyl Iodide in Air, Water and Blood by Means of its Reaction with Silver Nitrate; and Experiments Bearing on the Determination of Blood Flow by Means of Ethyl Iodide.

4. Starr, I., Jr., and Gamble, C. J., Am. J. Physiol., 1928, lxxxvii, 450. An Improved Method for the Determination of Cardiac Output in Man by Means of Ethyl Iodide.

5. Cattell, R. B., Boston Med. and Surg. J., 1926, cxcv, 69. The Elimination of the Iodine in the Urine in Normal Persons and in Exophthalmic Goiter.

6. Nyiri, W., Wien. Arch. f. inn. Med., 1925, ix, 511. Kurzfristige, einzeitige Nierenfunktionsprüfung mit Iodnatrium und Thiosulfat.

7. Wovschin, W. A., J. Am. Med. Assoc., 1915, lxv, 1101. The Elimination of Potassium Iodide in the Urine. An Experimental Comparative Study of its Administration by Mouth or Rectum.

8. Bolliger, A., Arch. Int. Med., 1928, xli, 642. Renal Function Tests with Sodium Thiosulfate and Sodium Iodide.

9. Henderson, Y., and Haggard, H. W., Am. J. Physiol., 1925, lxxiii, 193. The Circulation and its Measurement.

10. Starr, I., Jr., and Gamble, C. J., Am. J. Physiol., 1928, Ixxxvii, 474. The Behavior of Ethyl Iodide in the Body.

11. Fisher, H. L. Laboratory Manual of Organic Chemistry. New York, John Wiley and Sons, Inc., 1924, 2nd ed., pp. 50-51. 